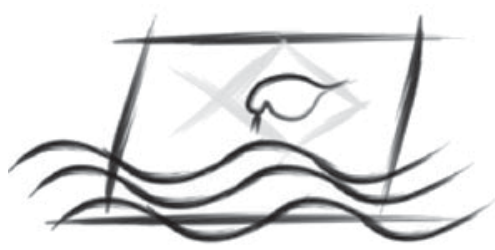

ECOTOX - Brazil
J. Braz. Soc. Ecotoxicol., v. 4 n. 1-3, 2009, 21-30

doi: 10.5132/jbse.2009.01.004

\title{
Anthropic Impact Evaluation of Two Brazilian Estuaries Trough Biomarkers in Fish
}

\author{
F. X. Valdez Domingos ${ }^{1 *}$, H. C. S. Assis ${ }^{2}$, M. D. Silva ${ }^{2}$, R. C. Damian ${ }^{3}$, \\ A. I. M. Almeida ${ }^{3}$, M. M. Cestari ${ }^{3}$, M. A. F. Randi ${ }^{1} \&$ C. A. Oliveira Ribeiro ${ }^{1}$ \\ ${ }^{1}$ Departamento de Biologia Celular, Universidade Federal do Paraná. CP 19031, CEP 81.531-990, Curitiba, PR, Brazil \\ ${ }^{2}$ Departamento de Farmacologia, Universidade Federal do Paraná. CP 19031, CEP 81.531-990, Curitiba, PR, Brazil \\ ${ }^{3}$ Departamento de Genética. Universidade Federal do Paraná. CP 19031, CEP 81.531-990, Curitiba, PR, Brazil
}

(Received August 28, 2008; Accepted August 11, 2009)

\begin{abstract}
Coastal and estuarine areas can be impacted by several sources of anthropogenic activities derived from industries, agriculture, sewage and harbor activities. Two Brazilian estuarine areas (Piraquê - ES e Paranaguá - PR) located close to harbours, industries and sewage from urban centers were evaluated through analysis of somatic indexes, histopathological, biochemical and genetic biomarkers on fish. Histopathological lesions as lamellar fusion, hyperplasia, epithelial lifting, and second lamellae disorganization were found in gills. Necrosis was the main alteration observed in the liver of sampled animals and the occurrence of melano-macrophages in Cathorops spixii was similar among the evaluated areas. Cholinesterase activity increased in most of the contaminated areas. Genotoxic responses as micronucleus induction and occurrence of DNA strand breaks were detected in Piraquê and Paranaguá estuaries in all sampling seasons. Our results suggest that these areas are impacted by anthropogenic activities and that a multi-biomarker approach is valuable and recommended for environmental pollution evaluation.
\end{abstract}

Keywords: histopathology, cholinesterase activity, genotoxicity, environmental contamination, toxic effects, Cathorops spixii, Lutjanus synagris

\section{RESUMO}

\section{Avaliação do impacto antrópico em dois estuários brasileiros por meio de biomarcadores em peixes}

Regiões estuarinas e costeiras são freqüentemente impactadas por vários tipos de influências antropogênicas derivadas de indústrias, agricultura, esgoto e atividades portuárias. Duas áreas estuarinas brasileiras (Piraquê - ES e Paranaguá - PR) foram biomonitoradas utilizando-se duas espécies de peixes por meio de índices somáticos e biomarcadores histopatológicos, bioquímicos e genéticos. Lesões histopatológicas como fusão de lamelas, hiperplasia, descolamento de epitélio, desorganização de lamelas secundárias e neoplasias foram encontradas nas brânquias. A principal alteração observada no fígado dos animais amostrados foi a necrose. A ocorrência de centros de melanomacrófagos no fígado foi similar entre as áreas avaliadas. A atividade da colinesterease foi mais elevada na maioria das áreas contaminadas. Respostas genotóxicas como a indução de micronúcleos e a ocorrência de quebras no DNA foram detectadas nos estuários de Piraquê e Paranaguá em todas as estações amostradas. Nossos resultados sugerem que estas áreas estão impactadas por atividades antrópicas e que a abordagem utilizando múltiplos biomarcadores é recomendada para a avaliação de poluição ambiental.

Palavras-chave: histopatologia, atividade da colinesterase, contaminação ambiental, efeitos tóxicos, Cathorops spixii, Lutjanus synagris. 


\section{INTRODUCTION}

Industrial, urban and agricultural wastes are the main sources of aquatic contamination, and polycyclic aromatic hydrocarbons (PAHs), polychlorinated byphenils (PCBs), organochlorine compounds (OCs) and heavy metals represent the most representative classes of contaminants frequently found in these environments (Oliveira Ribeiro et al., 2005; Ueno et al., 2004; Ueno et al., 2005; Hincka et al., 2008; Silva et al., 2009; Vicente-Martorell et al. 2009).

Toxic chemicals in the environment may affect aquatic organisms inducing several damages. General conditions of living organisms as growth, weight-length relationship, liver and gonad health status can be modified after exposure to chemicals. Thus, indexes as hepatosomatic, gonadossomatic and condition factor can be altered in fishes after exposure to pollutants (Teles and Santos, 2006; Hincka et al., 2008; Bervoets et al., 2009).

Histopathological lesions, disturbs on enzyme activity as well alterations on the integrity and functionality of DNA are some of these damages reported by previous studies in aquatic organisms from impacted areas due to human activities (Bombail et al., 2001; Fanta et al., 2003; de la Torre et al., 2005; Lemos et al., 2005; Lemos et al., 2006; Schlacher et al., 2007; Hincka et al., 2008; Valdez Domingos et al. 2007; Katsumiti et al., 2008; Silva et al., 2009). Necrosis areas, cellular vacuolization, inflammatory response, pre-carcinogenic or carcinogenic lesions are frequently observed in liver of fish environmentally exposed to PAH's, PCB's, heavy metals, sewage, harbor or industrial effluents (Schmalz et al.; 2002; Noreña-Barroso et al., 2004; Oliveira Ribeiro et al., 2005; Schlacher et al., 2007; Katsumiti et al., 2008; Silva et al., 2009). Lesions on secondary lamellae like fusion, epithelial lifting, hiperplasia of gills epithelial cells and aneurisms can also be detected in fishes from contaminated areas (Stentiford et al.; 2003; Noreña-Barroso et al., 2004; Oliveira Ribeiro et al., 2005; Schlacher et al., 2007; Katsumiti et al., 2008; Silva et al., 2009). Melano-macrophages can be induced by natural factors (aging, starvation and infectious diseases) or by exposition to contaminants, especially that associated with oxidative stress in cells. They can be observed as isolated pigmented cells (MM) or groups of pigmented cells (MMC) containing lipofucsine, ceroid, hemosiderin and melanin that occur in different organs as liver, head kidney and intestine of fish. Oxidative damage as lipid peroxidation induces the release of lipofucsin and consequently increase the occurrence of macrophage aggregates (Couillard and Hodson, 1996). The use of macrophage aggregates (MMCs) has been proposed by some authors as biomarkers of environmental pollution (Wolke, 1992; Couillard and Hodson, 1996; Stentiford et al., 2003; Rabitto et al., 2005).

The evaluation of cholinesterases activity (Sturm et al. 1999; de la Torre et al., 2005; Rabitto et al., 2005; Valdez Domingos et al., 2007; Solé et al., 2008; Bervoets et al. 2009) and chromosomal aberrations, breaks in DNA strains and occurrence of micronuclei and nuclear abnormalities (Bombail et al., 2001; Lemos et al., 2005; Porto et al., 2005; Lemos et al., 2006; Teles and Santos, 2006; Lemos et al., 2008) represent valuable biochemical and genotoxic parameters in environmental monitoring programs.

Studies performed on Brazilian coastal areas have increased in the last years, especially in south and southeast regions (Joyeux et al., 2004; Amado et al., 2006; Camargo and Martinez, 2006; Tortelli et al., 2006; Zanette et al., 2006; Valdez Domingos et al., 2007; Lemos et al., 2008; Katsumiti et al., 2008; Silva et al. 2009). As observed to other countries, in Brazil recent studies of environmental impacts in coastal areas are a matter of interest to understand the effects of pollutants on the aquatic organism's health and sea food quality. The use of biomarkers has been done in isolated studies and there are few data comparing different areas in order to establish species or standard methods to evaluate the impact of human activities on the Brazilian coast. The most recent investigations using a variety of biomarkers in Brazil have been concentrated in southern areas (Lemos et al., 2005; Amado et al., 2006; Camargo and Martinez, 2006; Zanette et al., 2006; Valdez Domingos et al., 2007; Katsumiti et al., 2008; Silva et al. 2009).

The objective of this study was to evaluate the effect of anthropogenic activities through different biomarkers in fishes environmentally exposed in two estuarine areas located on south and southeast Brazilian coast.

\section{MATERIAL AND METHODS}

\section{Study areas and sampling}

Adult individuals (males and females) representing two carnivorous species of fish were collected in two Brazilian estuaries in the present study (Figure 1): Cathorops spixii (Ariidae) in Paranaguá (PR) estuary, and Lutjanus synagris (Lutjanidae) in estuarine complex of Piraquê-Mirim and Piraquê-Açú rivers (ES) in August of 2003 (winter) and February of 2004 (summer). Ten individuals were used to evaluate the biomarkers proposed in the current work in each sampling site. Physicochemical parameters as temperature, salinity and $\mathrm{pH}$ were measured during the samplings. Fishes were anesthetized with benzocaine $200 \mathrm{ppm}$ before tissue sampling.

To study the impact of human activity two sites were chosen according to the distance from the most important source of contaminants in each studied area, where the reference (R) and contaminated (C) sites (Figure 1) were respectively more distant or close to the source of contaminants. Paranaguá estuary (Paraná State) receives agricultural, industrial and domestic sewage effluents as well as harbor related residuals. In this area the reference site was located at Laranjeiras estuary, a protected natural reserve (Teodoro, 2004). The most contaminated site in estuarine complex of Piraquê-Mirim and Piraquê-Açú rivers (Espírito Santo State) is affected by hydrogen peroxide, metal-mecanic, electronic and short fiber cellulose production plants and also receives agricultural, harbor and domestic sewage effluents. The presence of metals as $\mathrm{Cd}, \mathrm{Cr}, \mathrm{Cu}, \mathrm{Zn}$ and $\mathrm{Pb}$ was reported in fishes collected at Vitoria estuary (ES) by Joyeux et al. (2004). According to Niencheski et al. (2005) Zn, Cu and $\mathrm{Cr}$ were found bioaccumulated in liver and muscle of the same 


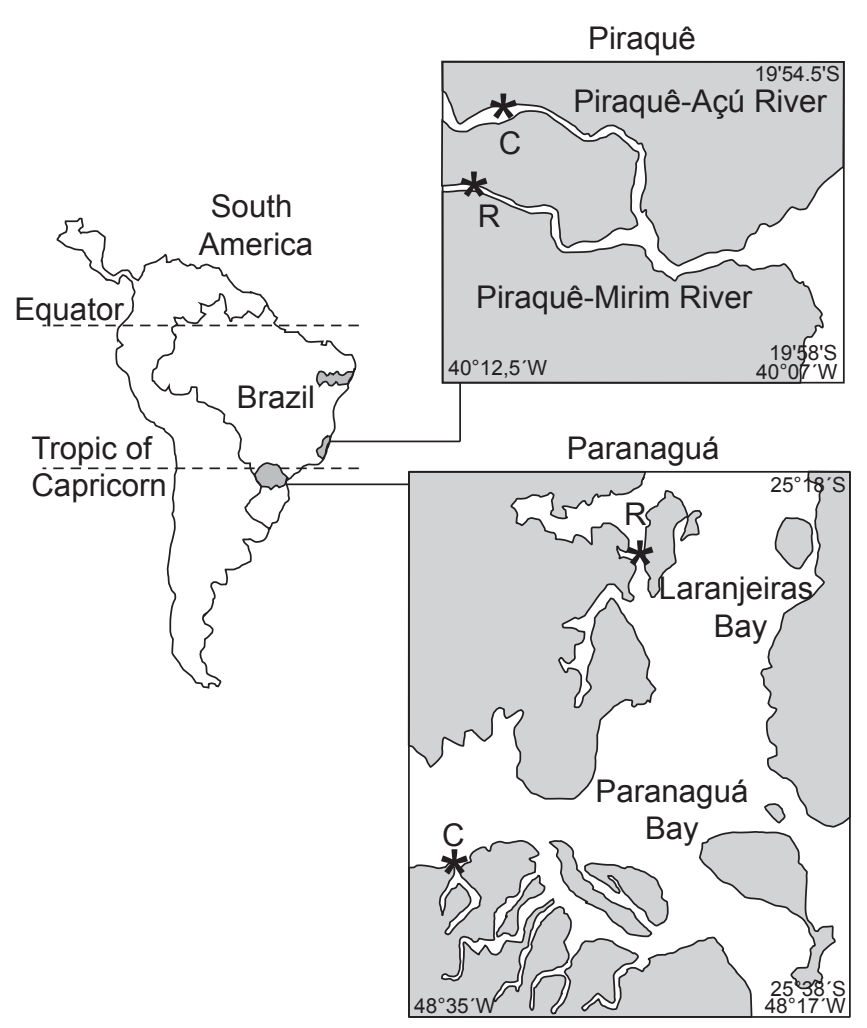

Figure 1 - Sampling sites along the Brazilian coast: Piraquê Espírito Santo and Paranaguá - Paraná estuaries. Reference (R) and contaminated (C) sites. Adapted from Zanette et al. (2006).

fish species and studied areas of the current work despite of the distance from the source of contamination.

\section{Somatic indexes}

Livers and gonads were weighed $(\mathrm{W})$ and somatic indexes calculated as follows: $\mathrm{HSI}=$ liver somatic index " $\left[\left(\mathrm{W}_{\text {liver }} \cdot \mathrm{W}_{\text {fish }}{ }^{-1}\right)\right] \times$ 100; GSI = gonadosomatic index $\left[\left(\mathrm{W}_{\text {gonad }} . \mathrm{W}_{\text {fish }}{ }^{-1}\right)\right] \times 100$; and the condition factor, $\mathrm{CF}=\mathrm{W}$ fish.(fish length $\left.{ }^{\mathrm{b}} .-1\right)$, where $\mathrm{b}$ is the angular coefficient of weight-length relationship.

\section{Histopathological analysis}

Gills and liver tissues were preserved by immersion in Alfac fixative solution, dehydrated in a graded ethanol series and embedded in Paraplast $\left(\mathrm{Sigma}^{\odot}\right)$. A lesion index of each studied fish was calculated for gills and liver after the histopathological analysis. A score value was attributed $(0$, 2,4 or 6 ) to the fish according to the occurrence of each kind of lesion, this value was then multiplied by the importance factor (1, 2 or 3) suggested by Bernet et al. (1999). The final fish score was composed by the sum of lesions detected in each fish (range: 0-18 for gills and 0-24 for liver). MMC and MM were evaluated according to the method proposed by Rabitto et al. (2005), 15 slide fields were analyzed for each fish and all MMC and MM were counted under a graduated eye piece. The results were expressed per $\mathrm{mm}^{2}$. Fish gills and fish liver fragments were fixed in a modified Karnovsky fixative solution (Glutaraldehyde 2,5\%, Paraformaldehyde $2 \%, \mathrm{CaCl}_{2}$ $2.5 \mathrm{mM}, \mathrm{NaCl}$ in Cacodylate 0.1 M pH 7.2-7.4) for two hours, embedded in PoliEMBED 812 resine (Electron Microscopy Sciences ${ }^{\odot}$ ) and analyzed in JEOL -1200 transmission electron microscope (TEM). For scanning electron microscopy (SEM) gills were fixed in $3 \%$ glutaraldehyde, $0.1 \mathrm{M}$ sodium cacodylate $\mathrm{pH}$ 7.2-7.4, washed in $0.1 \mathrm{M}$ sodium cacodylate buffer, dehydrated in graded ethanol series $\left(\mathrm{Merck}^{\circledR}\right)$, and the critical point was achieved with $\mathrm{CO}_{2}$. The samples were observed using a JEOL JSM-6360LV scanning electron microscope.

\section{Cholinesterase activity}

Muscle samples were homogenized (5\% w/v) in cold phosphate buffer $(0.05 \mathrm{M})$ containing $20 \%$ glycerol at $\mathrm{pH} 7.0$ and centrifuged at $850 \times \mathrm{g}\left(4^{\circ} \mathrm{C}\right)$ for 15 minutes. The supernatant was again centrifuged at $12,800 \times \mathrm{g}\left(4^{\circ} \mathrm{C}\right)$ during 15 minutes. The supernatant was used as enzyme source. To determine the substrate affinity $(\mathrm{Km})$ and maximum cholinesterase activity (Vmax), different acetylthiocholine iodide (AcSCh) concentrations ranging from 0 to $20 \mu \mathrm{M}$ were assayed. Cholinesterase activity was analyzed following the method described by Ellman et al. (1961) adapted for microplate. Protein concentration of each sample was determined according to Bradford's method (1976), using bovine serum albumin (BSA) as a standard.

\section{Genotoxicity analysis}

\section{Micronucleus (MN)}

A drop of fish blood was drawn over the slide to form a thin smear which was air-dried, fixed with absolute methanol (Merck), stained with Giëmsa in phosphate buffer pH 6.8 (Merck) (Ferraro et al., 2004). Two thousands erythrocytes of each sample were analyzed and scored for the presence of both typical micronuclei and nuclear alterations characterized as changes in the normal elliptic shape of the nuclei (Ayllon and Garcia-Vazquez, 2000).

\section{Comet assay}

The comet assay or single-cell gel test (SCGT) was performed according to Speit and Hartmann (1999). An aliquot of blood $(10 \mu \mathrm{L})$ was diluted in $1 \mathrm{~mL}$ of fetal calf serum. Microscopy slides were prepared using $10 \mu \mathrm{L}$ of this cell suspension and $120 \mu \mathrm{L}$ of low melting point agarose at $37^{\circ} \mathrm{C}$ followed by incubation in lysis solution $(1 \mathrm{~mL}$ of Triton X-100, $10 \mathrm{~mL}$ of DMSO and $89 \mathrm{~mL}$ of stock lysis solution $-2.5 \mathrm{M} \mathrm{NaCl}, 100 \mathrm{mM}$ EDTA, $10 \mathrm{mM}$ Tris, $10 \mathrm{mM}$ Na-lauroyl sarcosine) for 1 hour in the dark at $8{ }^{\circ} \mathrm{C}$. After lysis, slides were placed in buffer $(0.3 \mathrm{~N} \mathrm{NaOH}, 1 \mathrm{mM}$ EDTA, $\mathrm{pH}>13$ ) for 25 minutes to unravel the DNA. Electrophoresis was performed ( 25 minutes at $25 \mathrm{~V}$ and $300 \mathrm{~mA}$ ), and after this slides were neutralized in $0.4 \mathrm{M}$ Tris, fixed in absolute ethanol and stained with ethidium bromide $\left(0.02 \mu \mathrm{g} . \mathrm{mL}^{-1}\right)$ afterwards. Comets were scored using a Leica epifluorescence microscope. For each fish, a hundred cells were visually 
Table 1 - Water physicochemical parameters from studied estuaries along the Brazilian coast.

\begin{tabular}{llcccccc}
\hline \multicolumn{1}{c}{ Studied Areas } & \multicolumn{2}{c}{ Sites } & \multicolumn{3}{c}{ Winter } & \multicolumn{3}{c}{ Summer } \\
\hline \multirow{2}{*}{ Piraquê } & & $\mathrm{T}\left({ }^{\circ} \mathrm{C}\right)$ & $\mathrm{S}(\mathrm{ppt})$ & $\mathrm{pH}$ & $\mathrm{T}\left({ }^{\circ} \mathrm{C}\right)$ & $\mathrm{S}(\mathrm{ppt})$ & $\mathrm{pH}$ \\
& Reference & 23.9 & 35.0 & 6.1 & 29.7 & 20.8 & 10.1 \\
\multirow{3}{*}{ Paranaguá } & Contaminated & 24.1 & 33.5 & 7.1 & 28.7 & 17.6 & 11.3 \\
& Reference & 20.0 & 25.0 & 8.0 & 28.0 & 20.0 & 8.2 \\
& Contaminated & 22.0 & 23.0 & 7.9 & 28.0 & 17.0 & 8.4 \\
\hline
\end{tabular}

$\mathrm{T}=$ Temperature; $\mathrm{S}=$ Salinity

Table 2 - Somatic indexes of fishes collected in two estuaries on the Brazilian coast.

\begin{tabular}{|c|c|c|c|c|c|c|}
\hline Sampling & & Winter & & & Summer & \\
\hline Sites & HSI & $\mathrm{CF}$ & $\mathrm{R}^{2}$ & HSI & $\mathrm{CF}$ & $\mathrm{R}^{2}$ \\
\hline Piraquê R & $1.241 \pm 0.736^{\mathrm{a}, \mathrm{A}}$ & $0.008 \pm 0.0086^{a, A}$ & 0.9935 & $0.692 \pm 0.569^{\mathrm{a}, \mathrm{B}}$ & $0.015 \pm 0.0040^{\mathrm{a}, \mathrm{B}}$ & 0.7458 \\
\hline Piraquê C & $0.729 \pm 0.359^{a}$ & $0.016 \pm 0.0009^{a}$ & 0.9883 & $0.560 \pm 0.132^{\mathrm{a}}$ & $0.016 \pm 0.0012^{\mathrm{a}}$ & 0.9921 \\
\hline Paranaguá R & $1.261 \pm 0.219^{\mathrm{a}, \mathrm{A}}$ & $0.003 \pm 0.0002^{a}$ & 0.9328 & $1.596 \pm 0.296^{\mathrm{a}, \mathrm{B}}$ & $0.003 \pm 0.0005^{a}$ & 0.8529 \\
\hline Paranaguá C & $1.589 \pm 0.356^{\mathrm{b}}$ & $0.003 \pm 0.0004^{\mathrm{a}}$ & 0.7862 & $1.814 \pm 0.253^{\mathrm{a}}$ & $0.003 \pm 0.0012^{\mathrm{a}}$ & 0.7327 \\
\hline
\end{tabular}

Mean values \pm SD, ${ }^{\text {a, b }}$ indicate difference between reference and contaminated area and ${ }^{\mathrm{A}, \mathrm{B}}$ indicate difference between winter and summer. $\mathrm{n}=10$.

HIS = liver somatic index, $\mathrm{CF}=$ condition factor, $\mathrm{R}^{2}=$ correspondent to length weight regression.

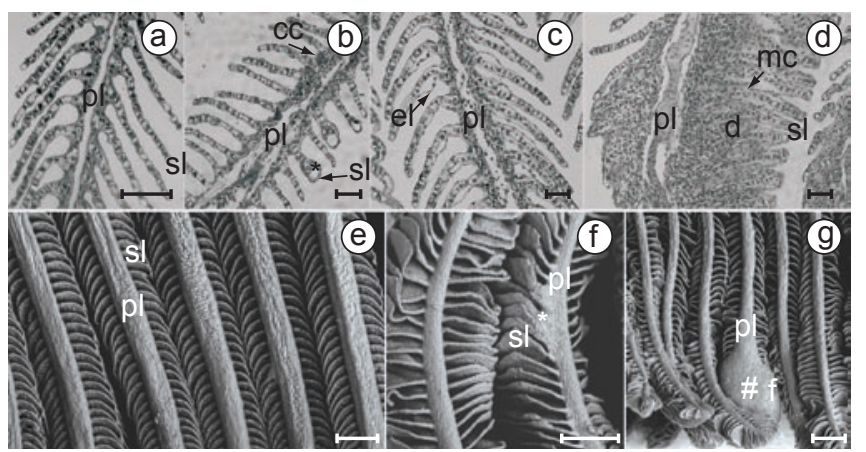

Figure 2 - Representative lesions observed on gills. a) Gill normal structure; note the organization of cells inside primary (pl) and secondary lamellae (sl). b) Note the vessels dilation on secondary lamellae extremities $\left(^{*}\right)$ and swelling of chloride cells (cc). c) Epithelial lifting on secondary lamellae (el). d) Fusion of secondary lamellae and mucous cells (mc) hypertrophy and proliferation. e) SEM gill normal structure, note the external structure of primary (pl) and secondary lamellae (sl).

f) Fusion $(*)$ on the base of secondary lamellae (sl). g) Complete fusion of secondary lamellae (f) and aneurism area (\#) adjacent to fusion. Scale bars $\mathrm{A}, \mathrm{B}, \mathrm{C}$ and $\mathrm{D}=50 \mu \mathrm{m} ; \mathrm{E}$ and $\mathrm{F}=100 \mu \mathrm{m}$ and $\mathrm{G}=200 \mu \mathrm{m}$.

analyzed according to Koestuaryashi et al. (1995), based on the migration of the fragments (tail size) (class 0 - no visible damage; class 1 - a short tail smaller than the diameter of the nucleus; class 2 - a tail length 1 to 2 times the diameter of the nucleus; and class $3-$ a tail length more than two times the diameter of the nucleus). Cells that presented a totally fragmented nucleus were considered as class 4 . A damage index was calculated multiplying the number of comets by its score value $(0,1,2,3$ or 4$)$, the index ranges from zero $(100 \times$ $0 ; 100$ observed cells with no damages) to $400(100 \times 4 ; 100$ observed cells with maximum damage).

\section{Statistical procedures}

Two kinds of comparison were performed for all biomarkers: reference versus contaminated area from each site and respective season and a seasonal evaluation comparing only reference or contaminated areas between summer and winter samplings. Enzyme activity, somatic index and melanomacrophage occurrence were compared through T-test; while histopathology, frequencies of micronuclei and comet assay results were compared through Mann-Whitney test. Enzyme kinetic parameters (Vmax and $\mathrm{Km}$ ) were estimated by Michaelis-Menten equation. Correlation among fish length, weight and cholinesterase activity was analyzed by Pearson correlation.

\section{RESULTS}

Differences on temperature were observed between winter and summer in both studied areas and the oscillation on salinity was more expressive in Piraquê estuary (Table 1).

The length of collected animals in each estuary was compared and did not present significant differences. CF was similar among individuals from reference $(\mathrm{R})$ and contaminated (C) sites in Paranaguá estuary on both seasons, HIS followed the same trend in summer, but in winter higher values on HIS were observed in the contaminated area. A seasonal comparison shows that HSI values were higher in summer than in winter (Table 2). Both somatic parameters presented similar values in Piraquê during winter and summer. Seasonal comparisons showed that in Piraquê HSI values were higher in winter and $\mathrm{CF}$ values were higher in summer (Table 2).

\section{Histopathology}

The most evident damages observed on gills were the epithelial lifting, lamellar fusion, hyperplasia and disorganization of lamellae structure (Figure 2). Vessels dilation on lamellae extremities and swelling of chloride cells are observed on Figure $2 \mathrm{~b}$ and epithelial lifting due to detachment of the epithelial cells layer on secondary lamellae in the Figure 2c. Lamellar fusion areas were often associated with hypertrophy and proliferation 


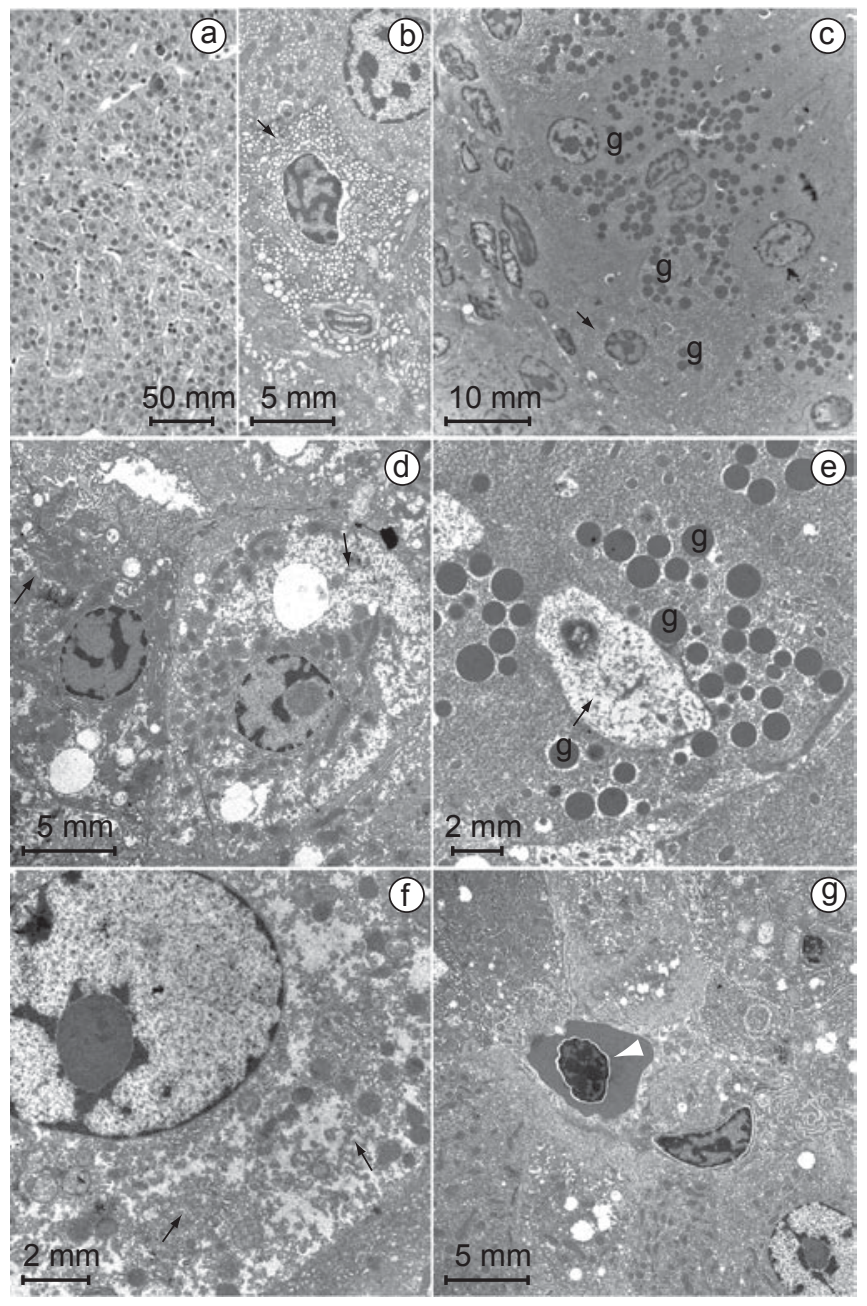

Figure 3 - Histopathological findings in liver. a) Liver organization under light microscopy. b) Smooth endoplasmic reticulum proliferation (arrow). c) Distribution of electron dense granuli (g) on hepatocytes cytosol.

d) Cytosolic disorganization indicative of necrosis (arrow); e) Area of focal necrosis (arrow), note the presence of electon dense granuli (g).

f) Cytosolic disorganization (arrows). g) Region of Disse's space organization

(d) with an erythrocyte in the sinusoid (white arrow). Images B to G were obtained through transmission electron microscopy.

of mucous cells and other epithelial cells found on primary lamellae between two or more secondary lamellae (Figure 2d). SEM results confirmed the fusion of secondary lamellae detected through light microscopy and demonstrated partial fusion located only at the base of secondary lamellae and a the presence of aneurisms (Figure $2 \mathrm{f}$ and $2 \mathrm{~g}$ ). The occurrence of histopathologic lesions on gills was similar between reference and contaminated areas of Paranaguá and Piraquê in both winter and summer, except for fishes from Paranaguá contaminated site in summer that presented lower gill lesions indexes than in Paranaguá reference sites.

The most expressive lesions identified by light microscopy studies in the liver of the studied species were necrosis, hepatocyte vacuolization (Figure 3) and leucocyte infiltrations. Through transmission electron microscopy (TEM) analyses was identified A proliferation of smooth endoplasmic reticulum proliferation (Figure $3 b$ ) and occurrence of numerous citosolic electron dense
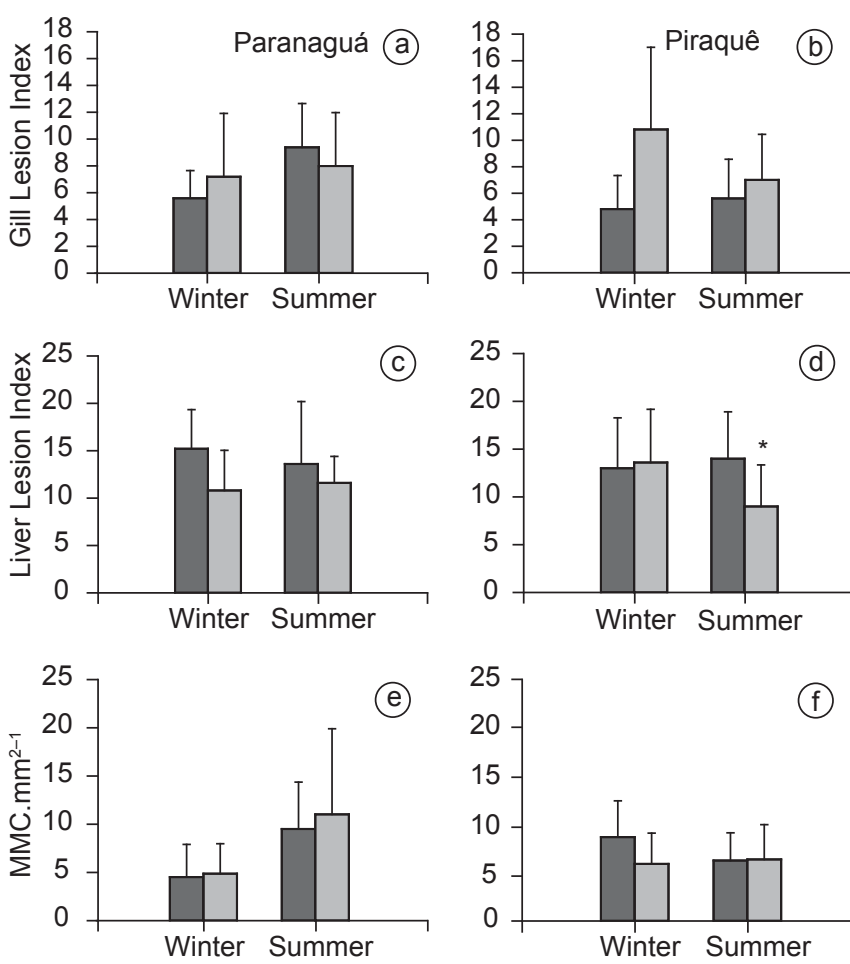

\section{Reference \\ Contaminated}

Figure 4 - Comparative lesions index (according to Bernet et al., 1999) in gills (a, b) and liver (c, d) of Lutjanus synagris and Cathorops spixii collected in Piraquê and Paranaguá estuaries respectively. Density of melanomacrophage centers (e) and free melanomacrophages (f) in Cathorops spixii collected in Paranaguá (mean \pm standard deviation).

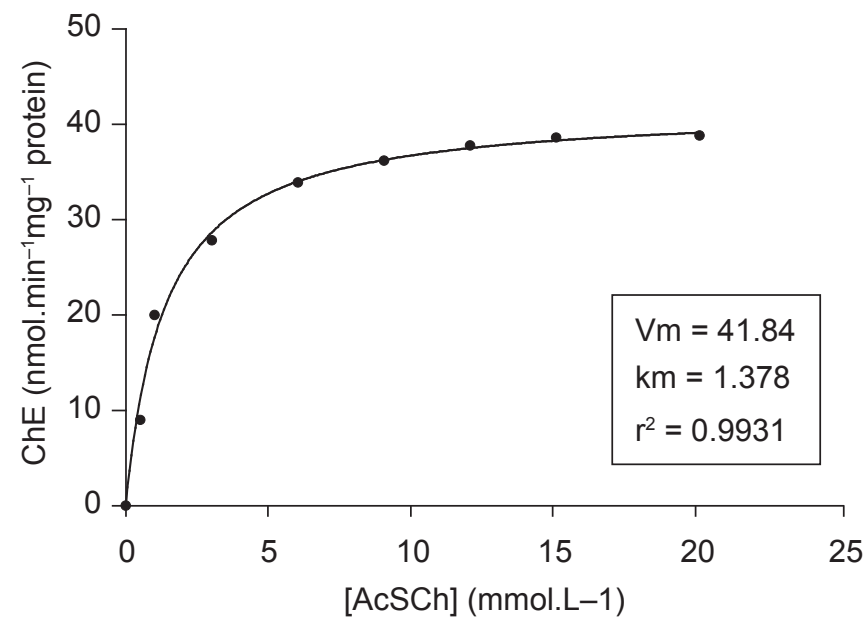

Figure 5 - Substrate affinity constant $\left(K_{\mathrm{m}}\right)$ and maximum activity $\left(V_{\max }\right)$ of muscle cholinesterase from Cathorops spixii. $K_{\mathrm{m}}$ is expressed in $\mu \mathrm{m}$ and $V_{\max }$ in nmol.min $\mathrm{ming}^{-1} \mathrm{mg}$ oroteins ${ }^{-1}$.

granules (Figure 3c and 3e). The presence of necrosis were visualized on both light and electron microscopy, this areas were recognized by focal tissue and cytosolic disorganization (Figure 3d, 3e, 3f). Gill lesions index was similar in reference and contaminated sites in Paranaguá and also in Piraquê in both seasons (Figure $4 \mathrm{a}$ and $\mathrm{b}$ ). Liver lesions index was similar in 


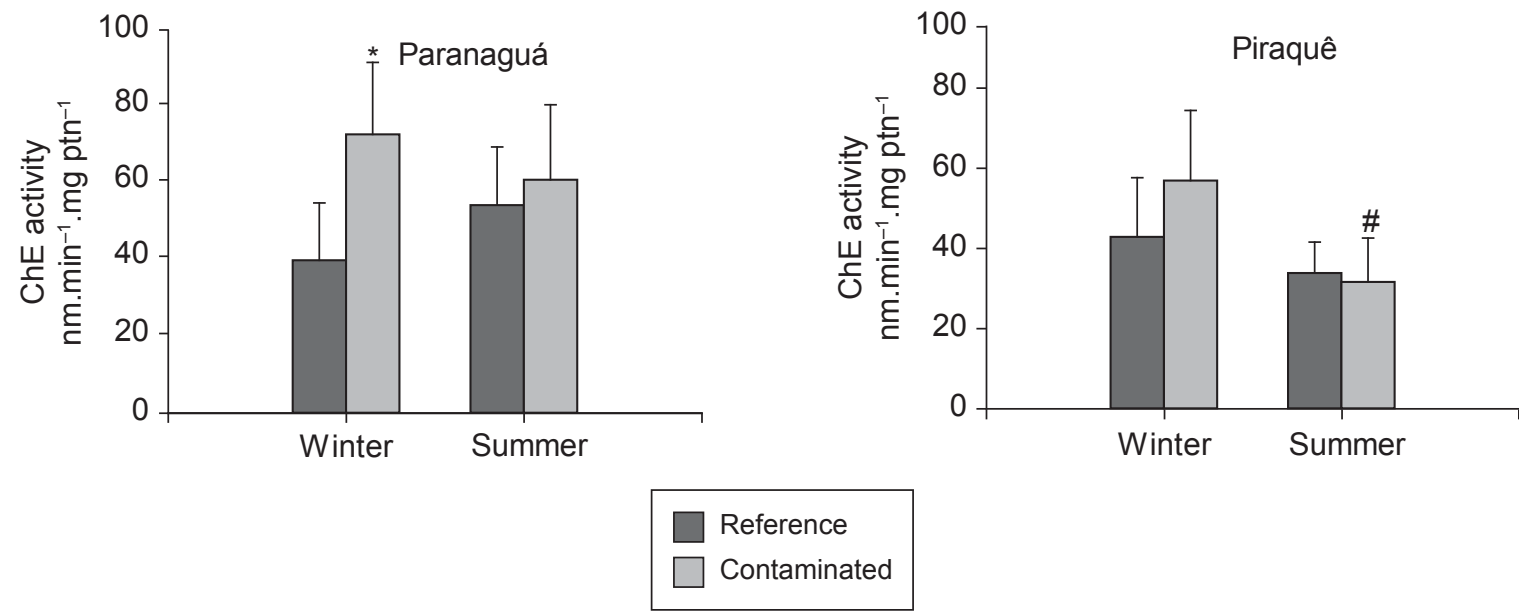

Figure 6 - Cholinesterase activity in Cathorops spixii and Lutjanus synagris collected in Piraquê and Paranaguá estuaries respectively (mean \pm standard deviation). *indicate significant difference between reference and contaminated sites in each season \# indicate significant difference between seasons for the same area (reference or contaminated) $(\mathrm{p}<0.05)$.
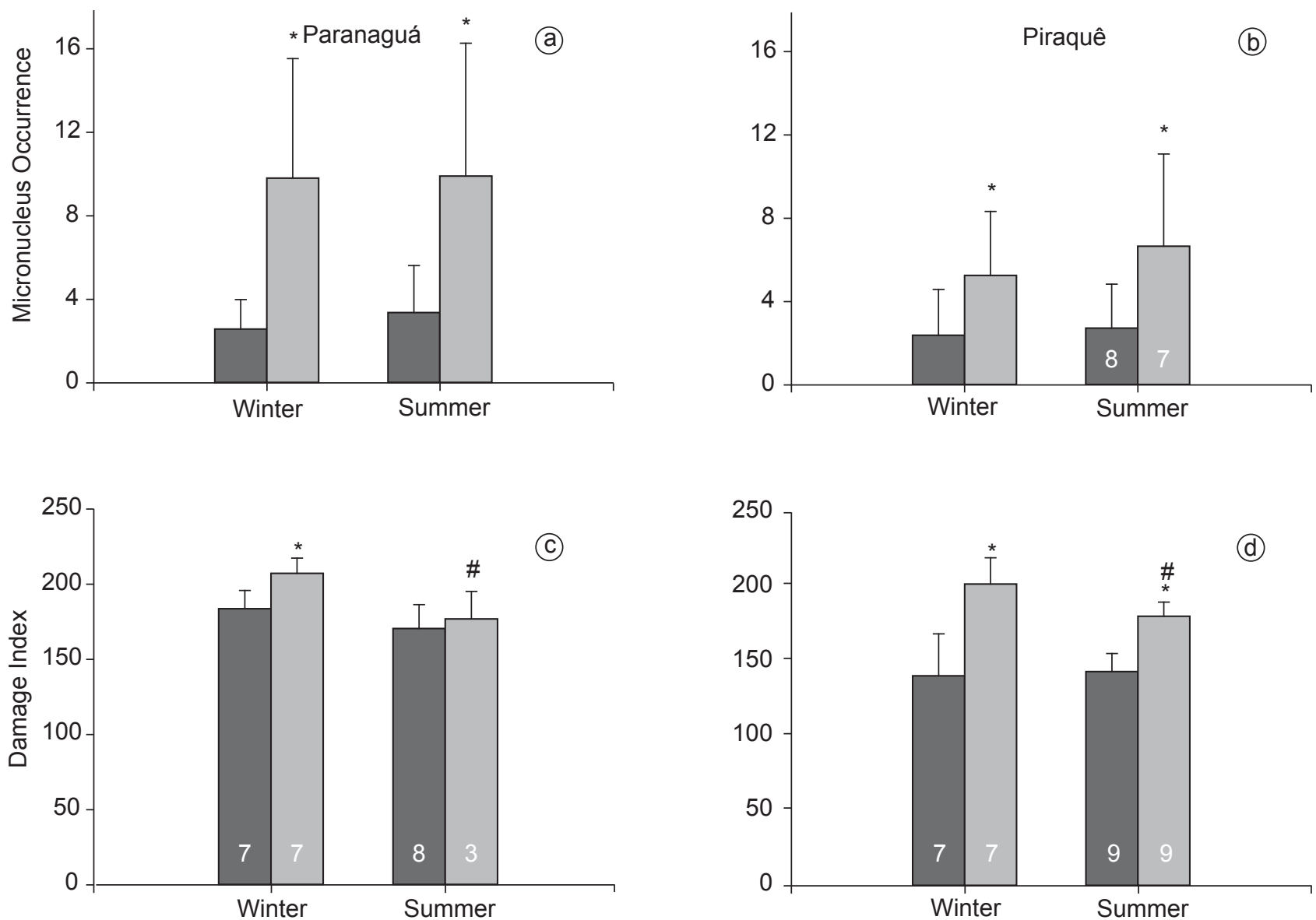

Reference

Contaminated

Figure 7 - Micronucleus occurrence (a, b) and DNA damage (c, d) in Lutjanus synagris and Cathorops spixii collected in Piraquê and Paranaguá estuaries respectively (mean \pm standard deviation). * indicate significant difference between reference and contaminated sites in each season, \# indicate significant difference between seasons for the same area (reference or contaminated) $(\mathrm{p}<0.05)$. Number inside graphics indicate when $\mathrm{n}$ is different from 10 . 
all sites (Figure 4c), except in Piraquê during summer where contaminated area presented lower index than the respective reference (Figure 4d). All individuals collected in Piraquê, did not present MMC or MM occurrence in liver neither in reference nor in contaminated sites. MMC occurrence was similar between reference and contaminated sites of Paranaguá in both seasons, as well isolated pigmented macrophages (MM) (Figure $4 \mathrm{e}$ and $\mathrm{f}$ ).

\section{Cholinesterase}

Based on the Michaelis-Menten constants (Km and Vmax) for muscle Ache, the concentration of $9 \mathrm{mM}$ of the substrate AcSCh (acetylthiocholine iodide) (Figure 5) was used to measure cholinesterase activity in both evaluated species.

A correlation among length, weight and cholinesterase activity from individuals collected in all studied sites was not observed. Fishes collected in Piraquê during winter presented negative correlation between AChE activity and length as well as between $\mathrm{AChE}$ activity and weight on $\mathrm{C}$ area. In summer a negative correlation was detected between weight (from $\mathrm{R}$ and $\mathrm{C}$ fishes) and length from $\mathrm{R}$ fishes with AChE activity $(\mathrm{p}<0.05)$. An increase in enzyme activity was observed in Paranaguá contaminated sites if compared with the respective reference site in winter. During summer Paranaguá presented similar cholinesterase activities. In general individuals collected in winter presented higher cholinesterase activities when compared with summer for both studied sites. This difference on Piraquê was significant for contaminated area in summer (Figure 6).

\section{Genotoxicity - micronucleus test (MN)}

Individuals from both Piraquê and Paranaguá estuaries in contaminated sites presented higher occurrence of $\mathrm{MN}$ than reference, and a lower level of nuclear abnormalities was found in individuals from Piraquê contaminated site if compared with Paranaguá reference site. After seasonal comparisons the reference or contaminated sites in Piraquê and Paranaguá estuaries did not presented differences (Figure $7 \mathrm{a}$ and $\mathrm{b}$ ).

\section{Genotoxicity - comet assay}

The occurrence of DNA damage in fishes from studied sites in Paranaguá estuary was similar in summer but a higher level of DNA damage was observed in contaminated site during winter. In comparison with Piraquê, the damages in DNA showed similar results with the studied sites in Paranaguá estuary. Comets incidence was similar between Piraquê reference site when compared summer and winter while the higher occurrence of DNA damage was observed in the contaminated site during winter (Figure 7c and c).

\section{DISCUSSION}

The effects of contaminants on the environment are generally evaluated in a focal area as an estuary, river or lagoon, besides that these studies seldom use one or few classes of biomarkers to perform an evaluation of the target environment (De la Torre et al., 2005; Oliveira Ribeiro et al.,
2005; Zanette et al., 2006; Lemos et al., 2008; Solé et al., 2008). In this work we presented an evaluation of multiple responses through somatic, histopathologic, biochemical and genetic biomarkers in two different estuarine areas affected by human activities along the Brazilian coast.

Somatic indexes were applied to assess the general condition of fish exposed to contaminants, this parameters were already used with a similar approach by Oliveira Ribeiro et al. (2005), Hincka et al. (2008) and Bervoets et al. (2009). CF is a general health index in which individuals exposed to contaminants can present not only lower values but the absence of differences, as reported in the current work for some sampling sites and by other authors (de la Torre et al., 2005; Bervoets et al., 2009). Fishes collected in contaminated sites frequently show increase in HSI and decrease in CF (Adams and Ryon, 1994, Bervoets et al., 2009). Our CF results were similar to de la Torre et al. (2005) and Bervoets et al. (2009). HIS results from Paranaguá during winter were similar to Adams and Ryon (1994) and Bervoets et al. (2009) findings. As fishes are able to bioaccumulate metals (Vicente-Martorell et al., 2009), PAHs (Liang et al., 2007; Perugini et al., 2007), chlorinated biphenils (Miranda et al., 2008) and polychlorinated biphenils (Oliveira Ribeiro et al., 2005) on their tissues when exposed to waterborne contaminants on the environment, increases on HSI can be associated to bioaccumulation of contaminants. According to Teles and Santos (2006) HSI can also indicate altered metabolic state on fish. As both studied species, Cathorops spixii and Lutjanus synagris present carnivorous feeding habits we expected to observe higher HSI in all contaminated areas as an evidence of pollutants bioaccumulation. This situation was observed only in Paranaguá sites. Based on HSI results we can conclude that only the organisms collected on the contaminated area of Paranaguá estuary were affected by pollutants.

Aquatic organisms exposed to multiple contaminants frequently present lesions in gills and liver, as reported in by Stentiford et al. (2003), Noreña-Barroso et al. (2004), Oliveira Ribeiro et al. (2005), Schlacher et al. (2007), Schmalz et al. (2002). Gills maintain direct contact with water and the presence of lesions in this organ is considered as an acute answer to the effects of chemicals (Akaishi et al., 2004). Fusion of lamellae was found in individuals from all studied sites and was reported to occur in fishes exposed to copper (Arellano et al., 1999), and PAH's (Katsumiti et al., 2008; Silva et al. 2009). Epithelial lifting on fish gills can be induced by copper and organophosphorus exposure, respectively (Arellano et al., 1999; Fanta et al., 2003). Epithelial lifting and lamellae fusion increase the distance between epithelial cells and vessels causing impairment on gas exchange process and also lead to disturbs in osmorregulation function, essential mechanisms to fish adaptation in stress conditions. The proliferation of mucous and other epithelial cells in gills suggest a protective mechanism in situations of impairment caused by waterborne pollutants or stress responses due to chemicals exposure. In addition cell and tissue hypertrophy can be an indicative of cellular dysfunction that can cause the development of neoplasic lesions, which were already registered in fishes chronically exposed to PAHs, 
chlorinated pesticides or PCBs (Noreña-Barroso et al., 2004; Oliveira Ribeiro et al., 2005).

Necrosis represented the most evident hepatic lesion found in this study and have been considered as a quite common lesion in fish collected in areas impacted by multiple contaminants (Schmalz et al., 2002; Stentiford et al., 2003; Oliveira Ribeiro et al., 2005; Katsumiti et al., 2008). The presence of this lesion in individuals from both reference and contaminated sites represents an indicative that the estuaries are widely impacted, even in areas distant from the main focus of contamination. Necrosis can cause functional and structural impairments to liver (Stentiford et al., 2003) as well disturbs on the functionality of the organ. Besides that, large and numerous necrotic areas can lead to organ failure causing impairments to the individual health, survival and in consequence can affect higher levels of biological organization, as populations and communities (Rabitto et al., 2005). Although The occurrence of necrotic areas has been observed in estuarine areas associated to the presence of pollutants as PAHs (Stentiford et al., 2003), chlorinated pesticides (Oliveira Ribeiro et al., 2005), heavy metals (Schmalz et al., 2002) and organophosphorus pesticides (Fanta et al., 2003). The incidence of lipid vesicles suggest a mechanism of lipophilic compounds immobilization as described by Oliveira Ribeiro et al. (2005) in Anguilla anguilla environmentally exposed to chlorinated pesticides, PAHs and PCBs. As described above the high incidence of liver lesions, (especially necrosis) observed on both species, indicate that all evaluated areas are subjected to environmental impact. The occurrence of melanomacrophage (MMC or MM) was similar among the analyzed areas, which corroborate the hypothesis that the status of both evaluated areas in each estuary is quite similar.

The occurrence of similar lesion indexes in gills and liver on both estuaries and seasons indicate that all areas are affected by human activities. A seasonal effect was not observed in this study, contrary to our results obtained with oysters on the same estuaries (Valdez Domingos et al., 2007). Our results confirm that histopathological biomarkers represent a valuable tool to evaluate environment quality. The results obtained through histophatology and somatic index data are in agreement with the presence of metals on these environments and confirm that both evaluated areas in each estuary are impacted.

Cholinesterase activity in fish and other aquatic organisms has been extensively used as biomarker of contamination in monitoring programs by different research groups (Sturm et al., 1999; Tortelli et al., 2006; Valdez Domingos et al., 2007; Solé et al., 2008). This endpoint is an efficient biomarker to detect sublethal effects of xenobiotics, mainly organophosphates, carbamates and some heavy metals (Sturm et al., 1999; Rabitto et al., 2005; Solé et al., 2008) that are classically known to cause enzyme inhibition. According to Akaishi et al. (2004) hydrocarbons can also inhibit cholinesterase activity on tropical freshwater fish. In the current work a trend of increase on cholinesterase activity were observed in Paranaguá, in both seasons, and in Piraquê during winter. The induction of this enzyme was also described to Puntius conchonius after exposure to endosulfan in muscle and liver (Gill et al., 1990). Negative correlations between AChE activity and fish length and between fish weight and AChE activity were observed in Piraquê. Similar results regarding to fish length was previously observed by Flammarion et al. (2002), indicating that is important to consider these parameters when evaluating AChE activity on field studies. Michaelis-Menten constants $\mathrm{Km}$ and Vmax showed different patterns in C. spixii collected in Paranaguá estuary reference and contaminated site. $\mathrm{Km}$ values were similar in both studied sites in summer while Vmax showed higher values in fishes from contaminated site. Similar result was also described by Thompson et al. (1991) in individuals chronically exposed to contaminants. A study conducted by Tortelli et al. (2006), showed that the formation of reversible enzyme-inhibitor complex was favored in fishes collected at the polluted site, while the irreversible enzymeinhibitor complex formation occurred in reference areas. Such findings can elucidate the lower activity values observed in the reference area from Paranaguá estuary. Another possible hypothesis to explain the increase of cholinesterase activity observed in the studied sites can be related with the presence of anticholinesterasic contaminants on the reference areas or $\mathrm{AChE}$ inducers on contaminated areas. The identification of the contaminants present on these estuaries is recommended to clarify the results.

Among all evaluated biomarkers, genotoxicity was the most sensitive endpoint to express differences between the evaluated sites in Piraquê and Paranaguá. The induction of DNA damage, micronucleus and DNA strands breaks, were higher on the sampling sites closest to the main contamination source. Induction of genotoxic effects was already demonstrated in fishes exposed to specific groups of contaminants as PAHs (Katsumiti et al., 2008), chlorinated hydrocarbons as DDT and PCBs (Porto et al., 2005), and heavy metals (Bombail et al., 2001; Porto et al., 2005) or environmentally exposed to mixtures of contaminants (Lemos et al., 2005; Amado et al., 2006; Lemos et al., 2008). Erythrocytic nuclear abnormalities and micronuclei occurrence were observed on fish exposed to petrochemical industry effluents by Lemos et al. (2008).

Morphological, somatic and genetic biomarkers showed that the estuarine regions evaluated are impacted by anthropogenic activities. The most sensitive biomarkers were the induction of micronucleus and DNA strand breaks. Our data showed that the use of different kinds of biomarkers is recommended when evaluating environmental pollution. They are also very useful to detect the impacted of human activities in aquatic ecosystems through the association of histopathological lesions with biochemical and genetic findings.

Our parallel survey using oysters as bioindicators (conducted on the same estuaries with the same classes of biomarkers), indicate that the answers of these organisms presented a seasonal effect specially on necrosis occurrence and cholinesterase activity (Valdez Domingos et al., 2007), this trend was not observed on our results with fishes. The data presented here reinforce which was presented on our previous study: the health status of the evaluated animals is quite similar inside the estuaries, indicating that there is a clear influence of contaminants on all evaluated areas. The results reported here can be considered as short (early warning) and medium term responses that can 
be harmful to the ecosystem health if environmental pollution control measures are not implemented.

Acknowledgements - This work was supported by Brazilian Ministry of Science and Technology (PROJETO RECOS INSTITUTO DO MILÊNIO - www.mileniodomar.org.br). Authors would like to thank all researchers and their staff for their helpful assistance during field work and initial laboratory procedures assistance in the following universities: UFPE, UFRPE, UFES and CEM-UFPR. Authors are grateful to Electronic Microscopy Center-CME of Federal University of Paraná (UFPR) for technical assistance. We also thank CAPES (Brazilian agency for Science and Technology assistance) for Valdez Domingos PhD fellowship.

\section{REFERENCES}

ADAMS, S. M. \& RYON, M. G., 1994. A comparison of health assessment approaches for evaluating the effects of contaminant-related stress on fish populations. J. Aquat. Ecos. Health., 3: 15-25.

AKAISHI, F. M., SILVA DE ASSIS, H. C., JAKOBI, S. C. G., EIRAS-STOFELLA, D. R., ST-JEAN, S., COURTENEY, S. C., LIMA, E. F., WAGENER, A. L., SCOFIELD, A. L. \& OLIVEIRA RIBEIRO, C. A., 2004. Morphological and Neurotoxicological Findings in Tropical Freshwater Fish (Astyanax sp) after Waterborne and Acute Exposure to Water Soluble Fraction (WSF) of Crude Oil. Arch. Environ. Contam. Toxicol., 46(2): 244-253.

AMADO, L. L., DA ROSA, C. E., LEITE, A. M., MORAES, L., PIRES, W. V., LEÃES PINHO, G. L., MARTINS, C. M. G., ROBALDO, R. B., NERY, L. E. M. \& MONSERRAT, J. M., 2006. Biomarkers in croakers Micropogonias furnieri (Teleostei: Sciaenidae) from polluted and non-polluted areas from the Patos Lagoon estuary (Southern Brazil): Evidences of genotoxic and immunological effects. Mar. Pollut. Bull., 52: 2, 199-206.

AREllano, J. M., STORCH, V. \& SARASQUETE, C., 1999. Histological changes and copper accumulation in liver and gills of the Senegales Sole, Solea senegalensis. Ecotoxicol. Environ. Saf., 44: 62-72.

AYLLON, F. \& GARCIA-VAZQUEZ, E., 2000. Induction of micronuclei and other nuclear abnormalities in European minnow Phoxinus phoxinus and mollie Poecilia latipinna: an assessment of the fish micronucleus test. Mutat. Res. - Genet. Toxicol. Environ. Mutag., Amsterdan, 467: 177-186.

BERNET, D., SCHIMIDT, H., MEIER, W., BURKHARDT-HOLM, P. \& WAHLI, T., 1999. Histophatology in fish: proposal for a protocol to assess aquatic pollution. J. Fish. Dis., 22, 25-34.

BERVOETS, L., CAMPENHOUT, K. V., REYNDERS, H., KNAPEN, D., COVACI, A. \& BLUST, R., 2009. Bioaccumulation of micropollutants and biomarker responses in caged carp (Cyprinus carpio). Ecotoxicology and Environmental Safety 72 , $720-728$

BOMBAIL, V. A. W. D., GORDON, E. \& BATTY, J., 2001. Aplication of the comet and micronucleus assays to butterfish (Pholis gunnellus) erythrocytes from the Firth of Forht, Scotland. Chemosphere, 44, 383-392.

BRADFORD, M., 1976. A rapid and sensitive method for the quantitation of microgram quantities of protein utilizing the principle of protein dye binding. Anal. Biochem., 72: 248-254.

CAMARGO, M. M. P. \& MARTINEZ, C. B. R., 2006. Biochemical and physiological biomarkers in Prochilodus lineatus submitted to in situ tests in an urban stream in southern Brazil. Environ. Toxicol. Pharmacol. 21, 61-69.

COUILLARD, C.M. \& HODSON, P.V., 1996. Pigmented macrophage aggregates: a toxic response in fish exposed to bleached kraft mill effluent? Environ. Toxicol. Chem. 15, 1844-1854.

DE LA TORRE, F. R., FERRARI, L. \& SALIBIÁN, A., 2005. Biomarkers of a native fish species (Cnesterodon decemmaculatus) application to the water toxicity assessment of a peri-urban polluted river of Argentina. Chemosphere. 59, 4, 577-583.

ELLMAN, G. L, COURTNEY, K. O., ANDRRES, V. \& FEATHERSTONE, R. M., 1961. A new and rapid colorimetric determination of acetylcholinesterase activity. Biochem. Pharmacol. 7, 88-95.

FANTA, E., RIOS, F. S., ROMÃO, S., VIANNA, A. C. C. \& FREIBERGER, S., 2003. Histopathology of the fish Corydoras paleatus contaminated with sublethal levels of organophosphorus in water and food. Ecotoxicol. Environ. Saf. 54, 119-130.

FERRARO, M. V. M., FENOCCHIO, A. S., MANTOVANI, M. S., OLIVEIRA RIBEIRO, C. A. \& CESTARI, M. M., 2004. Mutagenic effects of tributyltin and inorganic lead ( $\mathrm{Pb}$ II) on the fish H. malabaricus as evaluated using the comet assay and the piscine micronucleus and chromosome aberration tests. Genet. Mol. Biol. 27, 103-107.

FLAMMARION, P., NOURY, P. \& GARRIC, J. 2002. The measurement of cholinesterase activities as a biomarker in chub (Leuciscus cephalus): the fish length should not be ignored. Environ. ollut., 20, 2, 325-330.

GILL, T.S., JAISHREE, P. \& TEWARI, H., 1990. Enzime modulation by sublethal concentrations of aldicarb, phosphamidon, and endosulfan in fish tissues. Pestic. Biochem. Physiol. 38, 231-244.

HINCKA, J. E., BLAZER, V. S., DENSLOWC, N. D., ECHOLSA, K. R., GALEA, R. W., WIESER, C., MAYA, T. W., ELLERSIECKE, M., COYLEF, J. J. \& TILLITT, D. E. 2008. Chemical contaminants, health indicators, and reproductive biomarker responses in fish from rivers in the Southeastern United States. Sci. Total Environ. 390, 538-557

JOYEUX, J., FILHO, E. A. C. \& JESUS, H. C., 2004. Trace metal contamination in estuarine fishes from Vitória Estuary, ES, Brazil. Braz. Arch. Biol. Technol. 47, 5, 765-774.

KATSUMITI, A.; VALDEZ DOMINGOS, F. X., AZEVEDO, M., SILVA, M. D., DAMIAN, R. C., ALMEIDA, M. I. M., SILVA DE ASSIS, H. C., CESTARI, M. M., RANDI, M. A. F., OLIVEIRA RIBEIRO, C. A. \& FREIRE, C. A. 2008. An assessment of acute biomarker responses in the demersal catfish Cathorops spixii after the Vicuña Oil Spill in a harbour estuarine area in Southern Brazil. Environ Monit Assess. In Press.

KOESTUARYASHI, H., SUGIYAMA, C., MORIKAWA, Y., HAYASHI, M. \& SOFUNI, T., 1995. A comparison between manual microscopic analysis and computerized image analysis in the single cell gel electrophoresis. MMS Commun 3, 103-115.

LEMOS, N. G., DIAS, A. L., SILVA-SOUZA, A. T. \& MANTOVANI, M. S. 2005. Evaluation of environmental warters usin comet assay in Tilapia rendalli. Environ. Toxicol. Pharmacol. 19, 197201.

LEMOS, C. L., RÖDEL, P. M., TERRA, N. R., OLIVEIRA, N. C. D. \& ERDTMANN, B., 2006. River toxicity evaluation using micronucleus assay in fish erythrocytes. Ecotoxicol. Environ. Saf. 66, 3, 391-401.

LEMOS, C. T., IRANÇO, F. A., D’ÁVILA DE OLIVEIRA, N. C., SOUZA, G. D. \& GUIMARÃES FACHEL, J. M. 2008. Biomonitoring of genotoxicity using micronuclei assay in native population of Astyanax jacuhiensis (Characiformes: Characidae) 
at sites under petrochemical influence. Science Total Environ. In press.

LIANG, Y., TSE, M.F., YOUNG, L. \& WONG, M.H., 2007. Distribution patterns of polycyclic aromatic hydrocarbons (PAHs) in the sediments and fish at Mai Po Marshes Nature Reserve, Hong Kong. Water Res. 41, 1303-1311.

MIRANDA A.L., ROCHE H., RANDI M.A., MENEZES M.L. \& RIBEIRO C.A., 2008. Bioaccumulation of chlorinated pesticides and PCBs in the tropical freshwater fish Hoplias malabaricus: Histopathological, physiological, and immunological findings. Environ Int. 34, 7, 939-49.

NIENCHESKI, L.F; PINHEIRO JR, E.M; WALLNERKERSANACH, M; BAUMGARTEN, M.G.Z.; MACHADO, E.C.; SILVEIRA, I.M.O.; FLORES MONTES, M. \& RAMOS, J.F., 2005. Metais em peixes e organismos filtradores ao longo da costa Brasileira (projeto recos - instituto do milênio). In Anais do II Congresso Brasileiro de Oceanografia, Vitória, ES, Brasil, p. 1-3.

NOREÑA-BARROSO, E., SIMÁ-ÁLVAREZ, R., GOLD BOUCHOT, G. \& ZAPATA- PÉREZ, O., 2004. Persistent organic pollutants and histological lesions in Mayan catfish Ariopsis assimilis from the the Estuary of Chetumal, Mexico. Mar. Pollut. Bull. 48, 263- 269.

OLIVEIRA RIBEIRO, C. A., VOLLAIRE, Y., SANCHEZCHARDI, A. \& ROCHE, H., 2005. Bioaccumulation and the effects of organochlorine pesticides, PAH and heavy metals in the Eel (Anguilla anguilla) at the Camargue Nature Reserve, France. Aquat. Toxicol. 74, 1, 53-69.

PERUGINI, M., VISCIANO, P., GIAMMARINO, A., MANERA, M., DI NARDO, W. \& AMORENA, M. 2007. Polycyclic aromatic hydrocarbons in marine organisms from the Adriatic Sea, Italy. Chemosphere 66, 1904-1910.

PORTO, J. I. R., ARAUJO, C. S. O. \& FELDBERG, E., 2005. Mutagenic effects of mercury pollution as revealed by micronucleus test on three Amazonian fish species. Environ. Res. 97, 3, 287-292.

RABITTO, I. S., ALVES COSTA, J. R. M., SILVA DE ASSIS, H. C., PELLETIER, É., AKAISHI, F. M., ANJOS, A., RANDI, M. A. F. \& OLIVEIRA RIBEIRO, C. A., 2005. Effects of dietary $\mathrm{Pb}$ (II) and tributyltin on neotropial fish, Hoplias malabaricus: histopatological and biochemical findings. Ecotoxicol. Environ. Saf. 60, 147-156.

SCHLACHER, T. A., MONDON, J. A. \& CONNOLLY, R. M. 2007. Estuarine fish health assessment: Evidence of wastewater impacts based on nitrogen isotopes and histopathology. Mar. Poll. Bull. 54,1762-1776.

SCHMALZ, W. F., HERNANDEZ, A. D. \& WEIS, P., 2002. Hepatic histopathology in two populations of the mummichog Fundulus heteroclitus. Mar. Environ. Res. 54, 539-542.

SILVA, C.A., OLIVEIRARIBEIRO, C.A., KATSUMITI, A., ARAÚJO M.L.P., ZANDONA, E.M., COSTA SILVA, G.P., MASCHIO, J., ROCHE, H. \& SILVA DE ASSIS, H.C. 2009. Evaluation of waterborne exposure to oil spill 5 years after an accident in Southern Brazil. Ecotoxicol. Environ Saf., 72, 2, 400-409.

SOLÉ, M., LOBERA, G., ALJINOVIC, B., RÍOS, J., DE LAPARRA, L. M. G., MAYNOU, F. \& CARTES, J. E. 2008. Cholinesterases activities and lipid peroxidation levels in muscle from shelf and slope dwelling fish from the NW Mediterranean: Its potential use in pollution monitoring. Sci. Total Environ. 402, 306-317.

SPEIT, G. \& HARTMANN, A., 1999. The comet assay (single cell gel test) - a sensitive genotoxicity test for the detection of DNA damage and repair. In: Henderson, D. S. (Ed.) Methods in Molecular Biology: DNA repair protocols - eukaryotic systems, Totowa, 113, 203-212.

STENTIFORD, G. D., LONGSHAW, M., LYONS, B. P., JONES, G., GREEN, M. \& FEIST, S. W., 2003. Histopathological biomarkers in estuarine fish species for the assessment of biological effects of contaminants. Mar. Environ. Res. 55, 2, 137-159.

STURM, A.; SILVA DE ASSIS, H. C. \& HANSEN, P. D., 1999. Cholinesterases of marine teleost fish: enzymological characterization and potencial use in the monitoring of neurotoxic contamination. Mar. Environ. Res., 47:1-10.

TELES, M. P. \& SANTOS, M. A., 2006. Biotransformation, stress and genotoxic effects of $17 \beta$-estradiol in juvenile sea bass (Dicentrarchus labrax L.) Environ. Int. 32, 4, 470-477.

TEODORO, L. J. 2004. Poluição da Baía de Paranaguá. Relatório do Curso de Educação Ambiental: uma Introdução à Gestão Ambiental Portuária. Diretoria de Portos e Costas. Marinha do Brasil. Paranaguá, PR, Brazil.

THOMPSON, H. M., WALKER, C. H. \& HARDY, A. R. 1991. Changes in activity of avian serum esterases following exposure to organophosphorous insecticides. Arch. Environ. Contam. Toxicol. 20, 514-521.

TORTELLI, V., COLARES, E.P., ROBALDO, R.B., NERY, L.E.M., PINHO, G.L.L., BIANCHINI, A. \& MONSERRAT, J.M., 2006. Importance of cholinesterase kinetic parameters in environmental monitoring using estuarine fish. Chemosphere. 65, 560-566.

UENO, D., INOUE, S., TAKAHASHI, S., IKEDA, K., TANAKA, H., SUBRAMANIAN, A. N., FILLMANN, G., LAM, P. K. S., ZHENG, J. \& MUCHTAR M., 2004. Global pollution monitoring of butyltin compounds using skipjack tuna as a bioindicator. Environ. Pollut. 127, 1, 1-12.

UENO, D., WATTANBE, M., SUBRAMANIAN, A., TANAKA, H., FILLMANN, G., LAM, P. K. S., ZHENG, G. J., MUCHTAR M., RAZAK, H., PRUDENTE, M., CHUNG, K. \& TANABE, S., 2005. Global pollution monitoring of polychlorinated dibenzo-pdioxins (PCDDs), furans (PCDFs) and coplanar polychlorinated biphenyls (coplanar PCBs) using skipjack tuna as a bioindicator. Environ. Pollut. 36, 303-313.

VALDEZ DOMINGOS, F. X., AZEVEDO, M., SILVA, M. D., RANDI, M. A. F., FREIRE, C. A., SILVA DE ASSIS, H. C. \& OLIVEIRA RIBEIRO, C. A. 2007. Multibiomarker assessment of three Brazilian estuaries using oysters as bioindicators. Environ. Res. 105, 350-363.

VICENTE-MARTORELL, J. J., GALINDO- RIAÑO, M. D., GARCÍA-VARGAS, M. \& GRANADO-CASTRO, M. D., 2009. Bioavailability of heavy metals monitoring water, sediments and fish species from a polluted estuary. J. Haz. Mat. 162, 823-836.

WOLKE, R.E., 1992. Piscine macrophages aggregates: a review. Annu. Rev. Fish Dis. 2, 91-108.

ZANETTE, J., MONSERRAT, J. M. \& BIANCHINI, A., 2006. Biochemical biomarkers in gills of mangrove oyster Crassostrea rhizophorae from three Brazilian estuaries. Comp. Biochem. Physiol. 143 C, 187-195. 